\title{
PROBLEMS OF CREATING ACCOUNTABILITY \\ OF THE UNITED TERRITORIAL COMMUNITIES OF UKRAINE \\ IN THE SPHERE OF SUSTAINABLE DEVELOPMENT
}

\section{Svitlana Sliusar ${ }^{1}$ \\ Natalya Morosiuk ${ }^{2}$}

DOI: https://doi.org/10.30525/978-9934-588-15-0-93

Abstract. The purpose of this research is search of the solution of problem aspects of formation of self-sufficient, financially wealthy communities by the analysis of impact of the budgetary decentralization on formation of local budgets and budgets of the joint territorial communities (UTC) and acquaintance with rules of drawing up the reporting on budget implementation, about network, states and the contingents. Methodology. During the writing of the paper, the following research methods were used: the search for available methodological and scientific literature, comparison, clarification of causal relationships, systematization, analysis of documentation and results of researchers' work on the problem of the conducted research and expert evaluation. Results. To date, budgetary decentralization is the most effective and efficient way to ensure the financial autonomy and sustainability of local authorities by transferring to them powerful sources of budgetary revenues previously allocated to the central government and expanding the base of territorial units. That is, the introduction of a new model of financial support for local budgets is to expand the rights of local authorities, the sources of their formation, give them full budgetary autonomy and create a real ground for the exercise of their powers. And in connection with the amendments to the Budget Code on the introduction of medium-term planning, the issue of reporting and evaluation of the effectiveness of budget programmes is relevant for financial services workers. Practical implications. The UTC reporting system in Ukraine does not fully take into account all aspects of sustainable development and does not allow

${ }^{1} \mathrm{PhD}$ (Economics), Associate Professor,

Department of Finance of Accounting and Taxation,

Pereiaslav-Khmelnytskyi Hryhorii Skovoroda State Pedagogical University, Ukraine

${ }^{2} \mathrm{PhD}$ (Economics), Associate Professor, Leading Researcher,

National University of Life and Environmental Sciences of Ukraine, Ukraine 
to fully track the dynamics of the main indicators. The proposals are aimed not only at reforming the statistics of sustainable development led by local governments, but also at stimulating the capacity-building of new communities. Improved forms of statistical reporting will improve the quality of information received from UTC and improve the performance of regional and local authorities, in particular macroeconomic forecasts and the effectiveness of their management decisions. Value/originality. The paper proposes a mathematical model for determining the self-sufficiency index of rural territory. It is based on the methodology of calculation of the index of sustainable development by the Institute of Applied Systems Analysis of the National Academy of Sciences of Ukraine.

\section{Introduction}

One of the important problems in the formation of local budgets is the balanced socio-economic development of the regions and the formation of inter-budget relations in order to increase the level of financial self-sufficiency by strengthening budgetary decentralization. In order for a community to be able to carry out its tasks, it must have adequate financial resources to meet its own costs. It is likely that the formation of financially self-sufficient administrative-territorial units requires changes not only in tax and budgetary legislation, but also in the territorial size of communities, districts and regions. It is worth noting that the performance indicators reflect the overall socio-economic situation of the territory concerned and its potential for further development. The availability of sufficient resources in local budgets ensures that the territorial community is able to provide better and more diverse services to its inhabitants, to implement social and infrastructure projects, to create conditions for the development of entrepreneurship and investment capital, to develop local development programmes and to finance other measures to comprehensively improve the living conditions of the inhabitants of the community. The improvement of statistical reporting forms will improve the quality of information received from UTC and improve the functioning of regional and local authorities.

\section{Socio-economic importance of budgetary decentralization}

The main characteristic of a democratic State is to ensure the growth of the level of well-being of each individual citizen, and one of the main 
prerequisites for its development is to ensure the legal, organizational and financial autonomy of the system of local self-government bodies (LSB). At the present stage, Ukraine is steadily directing its efforts towards the implementation of the European integration policy and the fulfilment of international legal obligations, including on the development of local and regional democracy. That is why further democratization of society and, at the same time, decentralization of power on the basis of complementarity have been and remain Ukraine 's priorities.

Budgetary decentralization is the process of transferring powers (functions, competencies and responsibilities) from central authorities to local authorities [23]. The issue of budgetary decentralization is complex in the area of financial management. Although there is an urgent need to transfer authority to a lower level of authority in order to address certain issues, lower-level authorities generally do not have sufficient funds to exercise their new budgetary authority.

A unique start of budgetary decentralization was the introduction of amendments to the Budget and Tax Codes of Ukraine, according to which $[19 ; 20]$ : the autonomy of local budgets has been expanded due to the possibility of their adoption regardless of the adoption of the state budget; Some 50 sources of income are allocated to local budgets in order to improve the capacity to pay of communities; The balancing system of the budget clearing system has been replaced. The allocation of educational and medical subvention funds for the transfer of LSB transfers is assigned to line ministries; redistribution of spending powers by state authorities and local self-government bodies on the principle of complementarity; there is an incentive for territorial communities to unite and switch to direct inter-budget relations with the State budget. On this basis, the government aims to create a system in which there is a financial resource to work effectively for Ukrainian citizens. Therefore, within the framework of budgetary decentralization, not only incomes but also obligations under which local communities should act in the interests of local residents have to increase.

According to the reform, the budgets of the unified territorial communities (UTC) are given additional powers and appropriate financial resources, as cities of regional importance, in which $60 \%$ of the tax on the income of individuals remains. (NDFL), 100\% property tax (real estate, land, transport), 100\% single tax, 100\% retail excise tax (tobacco, alcohol, petroleum 
products), $100 \%$ tax on the income of public property institutions of UTC, $100 \%$ payments for the provision of administrative services, $25 \%$ environmental taxes, other fees and payments, Inter-budget transfers and programme and benefit income [24]. From budgets of UTC, except expenses on implementation of the self-coping powers, expenses which are delegated by the state it on execution, namely are financed: on the maintenance of institutions of the budgetary sphere - education, culture, health care, sport, social protection and social security. The expenditure of community budgets, not merged, is limited only to funding the costs of exercising self-governing powers, as they are deprived of the right to exercise powers that can be transferred by the state to perform LSB.

In addition, UTC budgets are involved in horizontal alignment [4, p. 19]. Clearing is carried out by one tax - tax on income of individuals. In order to increase their fiscal capacity, UTC budgets, which have a revenue level below the 0,9 average for Ukraine, are provided with a basic grant. From UTC budgets, which have a revenue level above 1,1 average in Ukraine, reverse grant is transferred. Community budgets, have not merged, do not participate in horizontal levelling of tax capacity, they are not provided with a basic subsidy.

According to the Code [19], budgets UTC provides for inter-budget transfers: basic grant, educational subvention, medical subvention, other subvention and grants. Community budgets, have not merged, will not receive inter-budget transfers from the state budget.

\section{Impact of budgetary decentralization on local budgets of Ukraine}

An important component of Ukraine 's full development in the context of budgetary decentralization is the formation of financially secure LSB, that is stable and sufficient sources of their content for the effective exercise by them of delegated, transferred to the field and their own powers on the one hand and the prompt solution of social and economic problems at the level of the territorial community on the other.

In almost every country, local budgets are the largest part of the budgetary system. Ukraine has more than 10,000 local budgets. Before the reform of local self-government, more than $70 \%$ of resources are concentrated in the state budget, the rest - more than $20 \%$ - in local budgets [9]. 
Since 2014 (Figure 1) there has been a gradual increase in the share of local budgets in the consolidated budget (from $37,5 \%$ in 2014 to $51,5 \%$ in 2018), which directly indicates the strengthening of the financial base of the LSB and is, in our opinion, a direct consequence of the implementation of the Concept of Reform of Local Self-Government and territorial organization of power in Ukraine, adopted on April 1, 2014.

The Law of Ukraine «On Local Self-Government in Ukraine» stipulates that «local budgets shall be sufficient to exercise the powers granted to them by law by the LSB and to provide the inhabitants of the respective communities with quality public services». As already mentioned, in the context of the analysis of the impact of decentralization processes on the local budgets of Ukraine, quite a lot of attention is paid to issues and problems related to the formation of their revenue part and the search for and realization of reserves for its filling.

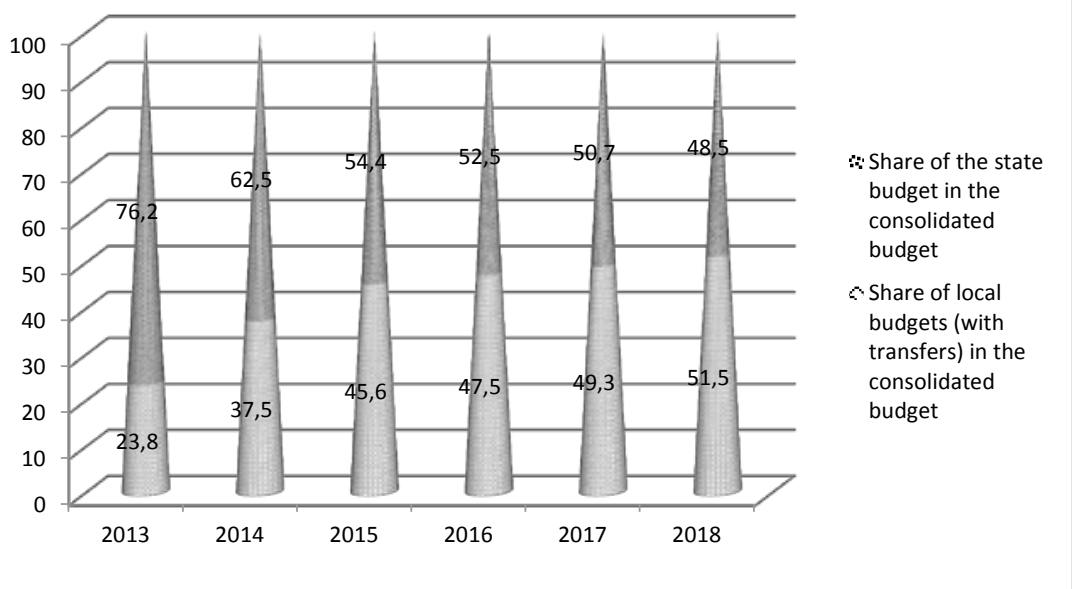

Figure 1. Dynamics of the share of local budgets (with transfers) in the consolidated budget of Ukraine for 2013-2018,\%

Source: Formed by authors on the basis of sources [8; 12]

However, it is worth noting that there has been a significant increase in State support for community development and infrastructure development (Figure 2), which is another positive consequence of budgetary decentralization and a direct step away from «driving» budgets into development budgets. 
As of August 1, 2018, the volume of total budget support to local authorities for the development of territorial communities and the development of their infrastructure amounted to UAH 14.9 billion, which is almost 30 times more than in 2015 (UAH 0.5 billion).

For these funds, 5904 projects were implemented to support local and regional development, and 523 LSB received funds for socio-economic development projects [6], which allows, with the support of the leading resources of the state, to implement their own development strategies.

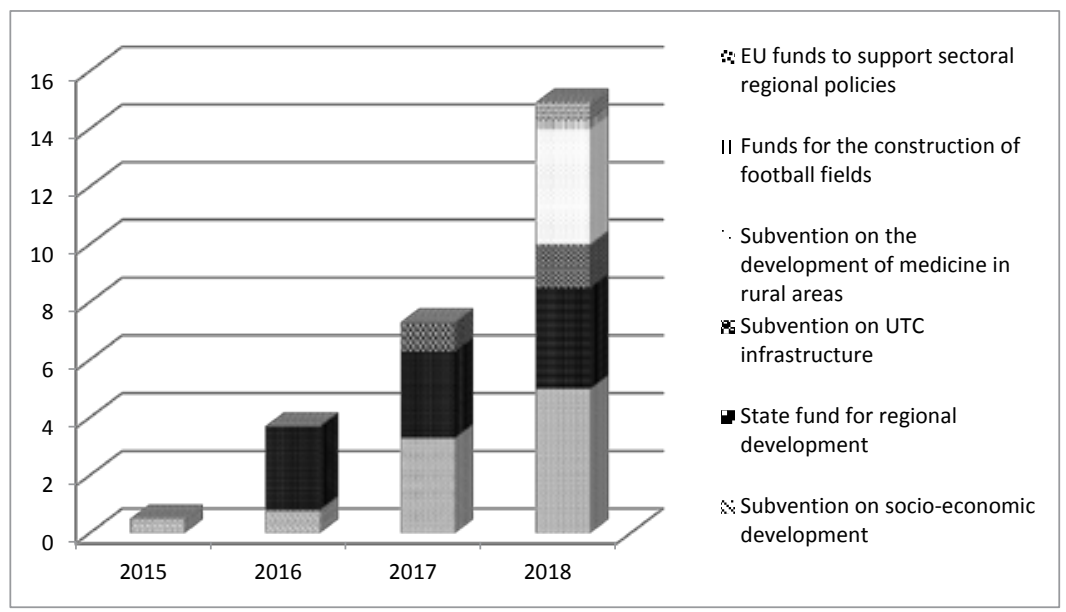

Figure 2. Dynamics of state support for community development and infrastructure development for 2015-2018, UAH billion

Source: Based on source [24]

Thus, the study of the impact of budgetary decentralization on the local budgets of Ukraine showed significant positive changes in the system of local self-government of the country. In addition, as a result of the reform, municipalities have become more independent and self-sufficient, they have serious means (by increasing their own revenues), which they are absolutely calm, without which instructions from the centre can use for the needs and development of society, which is certainly one of the significant benefits of financial decentralization. 


\section{Software-target method in UTC budget process}

In connection with the amendments to the Budget Code on the introduction of medium-term planning, the issue of reporting and evaluation of the effectiveness of budget programmes is relevant for UTC financial services workers.

The program-targeted method implies a transition from financing budgetary institutions on a residual basis to effective use of budgetary funds, is to lay down the principle of efficiency for a long period. It is worth noting that the latest changes to the Budget Code, which means the transition to medium-term planning and the formation of budgetary programmes exclusively taking into account the strategy of social and economic development of territorial communities.

UTC financiers should be able to analyze reporting data and use software on these issues, financial statements are submitted by UTC to the relevant Department of Regional Public Administration. Under the new legislation, community financial reporting indicators should be public, because the budget process is based on the principles of transparency.

UTC should understand that reporting is a mirror of their activities, because reporting data on forms, the Ministry of Finance proves, are formed on several aspects - reporting of budgetary institutions, efficiency of use of funds and implementation of budgetary programs. Communities receive financial information from the State and must reconcile, analyze the data, issue it in the form of an explanatory note and submit it to the Department of Finance. Most UTC of Ukraine provides timely and professional financial reporting, but in certain communities it is necessary to pay attention to weakness of personnel capacity. For example, if UTC returns funds to the State Budget as unused, it means that the financial service of the society does not provide an effective budgetary process. The society has not received services, infrastructure projects have not been implemented, and funds should be used for the development of the social sphere. And it is the reporting that allows UTC to analyze the indicators and ensure sustainable and timely funding for the socio-economic development of the territory.

The issue of financial reporting has always been addressed, but with the adoption of medium-term planning, the budget has begun to be analysed in greater depth. Assessing the effectiveness of local budgets helps to understand ways to save money and implement optimal programs in UTC, 
because we use the comparative base of past periods and understand where we have worked for positive and development. Here we introduced energy monitoring of all budgetary institutions and at the end of the year we realized that many premises are not effectively used, so it is relevant - optimization of work of certain spheres with preservation of the full volume of social and cultural services.

\section{System of indicators aimed at activation of UTC internal factors in the field of sustainable development}

Traditionally, the indicator system is divided into three groups: economic, social and environmental, which in turn are divided into many subgroups. For example, economic indicators could be grouped into economic, structural, investment, financial, economic and technological capabilities; social - combine indicators of the standard of living of the population, the state of the labour force, the health of the population, the demographic situation and the criminal situation [1]. These subgroups are in turn divided into separate indicators. The thought that measurements in economic, social, ecological spheres should be added with indicators social and economic, ecologically economic, social-and-ecological, socio-ecological-economic partners is proved in scientific literature.

With regard to the development index, for example, nine groups can be identified to characterize certain aspects of the level achieved and trends in the development of the potential of the region: demographic development, labour market development, material well-being of the population, living conditions of the population, level of education of the population, state of health, social environment, environmental situation, financing of human development [22].

The partial indicators of the consolidated index of the level of development of the region are a kind of indicator of structural regional shifts and should be used in determining regional policy priorities. From this position, the system of indicators is divided into three blocks: structural-proportional development of the economy; institutional development; interregional ties and social development of regions [2].

The disadvantage of the vast majority of evaluation systems lies in the fact that the ultimate purpose of their development is to type (classify) regions or other administrative-territorial units according to the level of 
socio-economic development, rather than to analyze the current situation, assess existing trends and monitor the implementation of strategic directions of state, regional and local policy. In assessing the socio-economic development of the region, it is necessary to take into account its dual nature: on the one hand, as an element (subsystem) of the high-level system - the country, and on the other - as a relatively independent system, the elements (subsystems) of which are administrative-territorial units. At the same time the purpose of this assessment most of scientists see in typification of objects with division them on the following groups: leading objects, advanced, developed and problem [1].

In addition, in practice, it is impossible to implement most methods due to lack of official data, and to require the provision of reporting by enterprises, institutions and organizations, is not provided for by normative and legal acts, according to the legislation of Ukraine is prohibited.

Given the subjectivity of socio-economic categories, it is important to adequately reflect the second element. This requires not only the development of minimum social standards for the provision of facilities and services for enterprises and institutions of social infrastructure to rural populations, as well as the guarantee of compliance with these standards by the government. It is obvious that it is not appropriate to use the social standards and regulations that apply in the state. Their aim is to provide the minimum necessary list of needs of the population, and the aim of the development of society is to ensure a decent standard of living for them. In the domestic literature, for example, it is proposed to focus on social standards of developed countries of the world, especially European ones.

According to the rank (weight) of the indicator, it will depend on the priority of a certain component of the standard of living of the population at present. Thus, if there is a large proportion of the poor in society, the priority for such a community will be to provide the inhabitants of the community with the first material level of needs. If this level is met, other priorities can be targeted while allowing lower levels of satisfaction to be reduced. It is necessary to determine the rank of indicators with the involvement of the public, state and local authorities, scientists, experts.

The system of assessments should cover all hierarchical levels of government from the state to the lowest - local. At present, Ukraine does not have it, although there are some developments, in particular, quite a lot of 
studies have been carried out on the regional level $[1 ; 2 ; 5 ; 16 ; 17]$. According to the legislation in force, the assessment of rural development is not comprehensive $[7 ; 10 ; 18]$.

Unlike Ukraine, countries of the world, including western European countries, in the context of the concept of sustainable development, a slender system of assessment of the level of development of territories has been developed, which covers all degrees of governance from international to individual municipalities. Thus, pursuant to section 40 of Agenda 21, the relevant commission at the United Nations (UN), a system of indicators has been developed to measure the level of sustainable development of countries. They are divided into four groups: social (equality, health, education, households, safety, population), economic (economic structure, production and consumption), ecological (condition of the atmosphere, lands, oceans, seas and coastal zone, water quality and biodiversity) and institutional (frame conditions, institutional construction).

In parallel with the UN commission, other international bodies and organizations have worked on this issue: Eurostat, the World Bank, the Organization for Economic Cooperation and Development, etc. Thus, the World Bank 's Annual Development Report contains about 80 indicators divided into 6 groups.

Given the above, the systems for measuring sustainable development used at the international level are too cumbersome. They are suitable for measuring and comparing different aspects of the development of the States of the world, but for a number of reasons are not suitable for assessing the development of municipalities. In particular, the functioning of territorial socio-economic systems directly affects the daily life of every person. This requires assessment systems to specify certain parameters, and some internationally important indicators at the local level may be of secondary importance.

The most difficult task in the formation of systems of assessments of territory development is to determine the list of indicators at the municipal level. There is considerable experience in measuring sustainable development at the human settlements level in Western European countries, each of which has developed its own strategy to implement international instruments.

In Western European countries, there is no single scheme for their construction. In each settlement, depending on the purpose of development, a system of its own is formed. So, in Germany (the city of Hokeinheim) 
indicators are grouped into five groups: ecology, economy, society or social development, participation and additional indicators. At the same time, in the city of Trepkov-Kepenik their list is considerably limited and is traditionally divided into environmental, economic and social indicators [21].

Although each locality is developing its own system of indicators, a number of common points can be made. Thus, in the strategies of sustainable development we have studied [25-29], energy conservation and environmental aspects - air pollution, water bodies, waste storage and recycling - are a priority. An important place is occupied by a block of indicators aimed at creating comfortable living conditions for the local population by solving such problems as improving housing conditions, accessibility of public transport, ensuring peace and quiet. Economic development is focused on supporting local entrepreneurs, especially socially and socially useful enterprises, balancing the structure of the economy and ensuring a high level of employment. Almost all systems include an assessment of the participation of the population in the public life of the municipality, cooperation with the international community and the contribution of the Territory to solving global problems.

For the purpose of observing the course of this process and monitoring, traditionally the indicators of sustainable development of the region are divided into economic (production-economic, structural, investment, financial, scientific and technical potential, foreign economic activity), social (living standards of the population, social infrastructure, labour resources, health of the population, demographic situation, crime situation), environmental (state of the natural environment, anthropogenic impact on the natural environment, use of natural resources, use of output or secondary resources) [3].

Considering that the development of territories is a dynamic process, T.O. Zinchuk proposes to divide its indicators into three groups: deterministic, fixed and efficient. Deterministic indicators are used to characterize the resource provision of social development and provide for the assessment of the productivity of the village. Fixed indicators show the social situation of processes and phenomena in rural areas and include five axes of indicators: population, employment, working conditions, standard of living, social infrastructure. Performance indicators are indicators that include the basic parameters of the social well-being of the rural population [11, p. 329-338]. 
As an option for determining socio-economic development factors, it is proposed to use correlation-regression analysis methods. However, according to R. A. Kulinich, the use of this method is possible in normal distribution, which is rare in the economy. As a result, for example, factors between which there is a functional dependence may not be detected, will lead to erroneous conclusions and inadequate reflection of the investigated object [13]. Taking this into account, we propose that in determining indicators of sustainable development of rural areas we give preference not to statistical and mathematical methods, but to the thoughts of experts: population, local self-government officials, scientists.

Based on the research carried out and taking into account domestic scientific developments in the field of rural areas and foreign experience, we propose a system of indicators for the system of management of territorial social communities. Their choice is based on socio-economic criteria of self-sufficiency of communities, namely: expanded reproduction of human capital, availability of vital benefits, formation of a full economic sphere, ensuring financial autonomy of rural self-government bodies, rational use and reproduction of natural resources $[14 ; 15]$.

The whole set of indicators for ease of use is divided into traditional three groups: economic, social and environmental. The economic group includes the following indicators:

- production of gross agricultural products (in comparable 2010 prices) per 100 hectares of agricultural land;

- volume of industrial products sold per 1 person; Number of small enterprises per 1,000 population (excluding agricultural);

- the number of entrepreneurs per 100 people;

- retail trade per 1 person;

- volume of services sold per 1 person;

- number of service cooperatives;

- the unemployment rate of the population;

- the amount spent on average per 1 employee - resident of the community (provided for in the collective agreement);

- income from entrepreneurial activity on 1 individual entrepreneur; Personal peasant income per 1 person;

- average monthly wage of employees;

- part of the population with average per capita expenses per month is below the subsistence minimum; 
- the average amount of social assistance provided to 1 person;

- tax revenues to the local budget;

- income to the local development budget;

- receipt of charges for the rental of utilities and premises.

In order to determine the level of social development of rural areas, we propose the following indicators:

- number of children under 18 per 1,000 population;

- number of young people (18-30 years) per 1000 population;

- natural population growth per 1,000 population;

- number of persons who have left rural areas in a year;

- number of persons assisted (out-patient and during emergency medical visits) per 1,000 population;

- emergency care costs for human 1 ;

- incidence of infectious diseases and tuberculosis per 1,000 population;

- mortality of children under one year of age per 1,000 births;

- coverage of children by preschool institutions;

- the number of graduates of general education institutions who have entered higher education institutions;

- the proportion of the population of the territory that has a basic or higher education (persons studying in higher education institutions of the I-IV accreditation level have an educational and qualification level bachelor, specialist, master);

- number of club-type establishments per 1 village;

- costs of maintenance of socio-cultural facilities;

- updating the library book fund;

- sports facilities per 100 population;

- Length of street lighting; Street greening costs;

- commissioning of housing for 1,000 people;

- share of the housing stock of gasified, equipped with water supply and sewerage;

- number of recorded crimes per 100 population.

In the environmental field, given the relevance of mechanisms to protect the rural environment and to compensate communities for losses, the following indicators should be used:

- the amount of waste water discharged into natural surface water bodies;

- emissions of harmful substances into the atmospheric air; 
- presence of hazardous waste;

- environmental costs;

- the share of environmental fees actually paid in the total amount charged.

The proposed system of indicators is indicative. In practice, it should be flexible at the municipal level. Thus, there are more than 28,000 in Ukraine. Rural settlements and 11,000 Village councils, which vary considerably in the quality characteristics of their inhabitants (age structure, level of education, etc.). According to the needs, the motives and objectives of these communities are also different. This was confirmed by what we conducted in 2008. Survey of rural residents of the Zhitomir region: for young people, the first priority is the availability of educational institutions and the possibility of cultural leisure, while for the vast majority of older persons it is the availability of health care institutions.

Public awareness of their needs and development goals is reflected in strategic planning. In particular, a common practice in the world is along with the preparation of an analytical report, opinion polls, which can produce rather unexpected results. For example, sociological studies of rural communities indicate that their inhabitants are primarily interested in the deterioration of the crime situation, rather than employment, the availability of social infrastructure and the like.

At the same time, the active participation of the population in the strategic planning process is important to take into account the needs of all residents, regardless of their property, age or social status. In addition, it should be borne in mind that the «rules of the game» in rural areas are formed on the one hand on the basis of official legal acts, on the other - under the influence of informal factors. Taking into account the specifics of the rural lifestyle, interpersonal relations and informal communication play a very important role here. There is a situation where decision-making, imposed on the top by peasants are not implemented, or are implemented, but the result does not correspond to the expected one.

The implementation of the biosocial concept of rural development is possible only if a competitive environment is created. For this purpose, society should be compared, which in turn requires some unification of assessment systems at the district and regional levels. There are usually a number of methodological problems. Thus, the difficulty of building any 
model of rural development lies in the lack of completeness of information and the inability to obtain it. According to Ukrainian legislation, it is allowed to demand that economic entities provide reports not provided for in the normative and legal acts. The task of selecting indicators complicates the fact that the regions of Ukraine differ significantly in natural and socio-economic conditions. In view of this, the indicators should be proportional either per person or per area, in other cases relative indicators should be used.

Another methodological problem is the comparability of indicators for certain critical values, below which system failure will begin.

This requires the establishment of a system of State social standards for the provision of social infrastructure to rural populations, as well as the guarantee of compliance by the government with these standards.

On the basis of the above, we have proposed a mathematical model for determining the rural self-sufficiency index (Figure 3). It is based on the methodology of calculation of the index of sustainable development by the Institute of applied system analysis of the National Academy of Sciences of Ukraine.

Taking into account the requirement of coherence of the components of sustainable development, they considered the index of sustainable development $\left(I_{s d}\right)$ as a vector whose norm determines the level of sustainable development, and its spatial position in the coordinate system $\left(I_{e c}-\right.$ economic, $I_{e}$ - environmental, $I_{s}$ - socio-institutional) characterizes the degree of harmonization of sustainable development (G) [14].

The equidistance of the $I_{s d}$ vector from each of the coordinates $I_{e c}, I_{e}, I_{s}$ will correspond to the greatest harmony of sustainable development. The approximation of this vector in one of the coordinates indicates the priority development of this direction and ignoring the other two. Each index is calculated on the basis of six internationally accepted global indices $I_{e c}$ (global competitiveness index and economic freedom index), $I_{e}$ (environmental measurement index), $I_{s}$ (quality of life index, human development index and knowledge society index) [14].

In the process of self-sufficiency formation communities to use an integral index. So, its magnitude will be to indicate the level of self-sufficiency of the community. In addition, integral the index will ensure that the level of community development is comparable. 


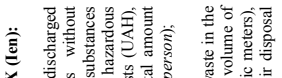

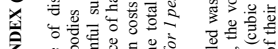

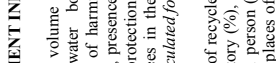

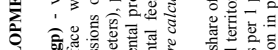 \\ 舟

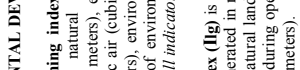

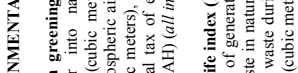

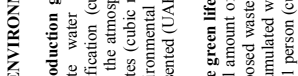

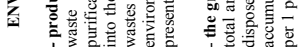
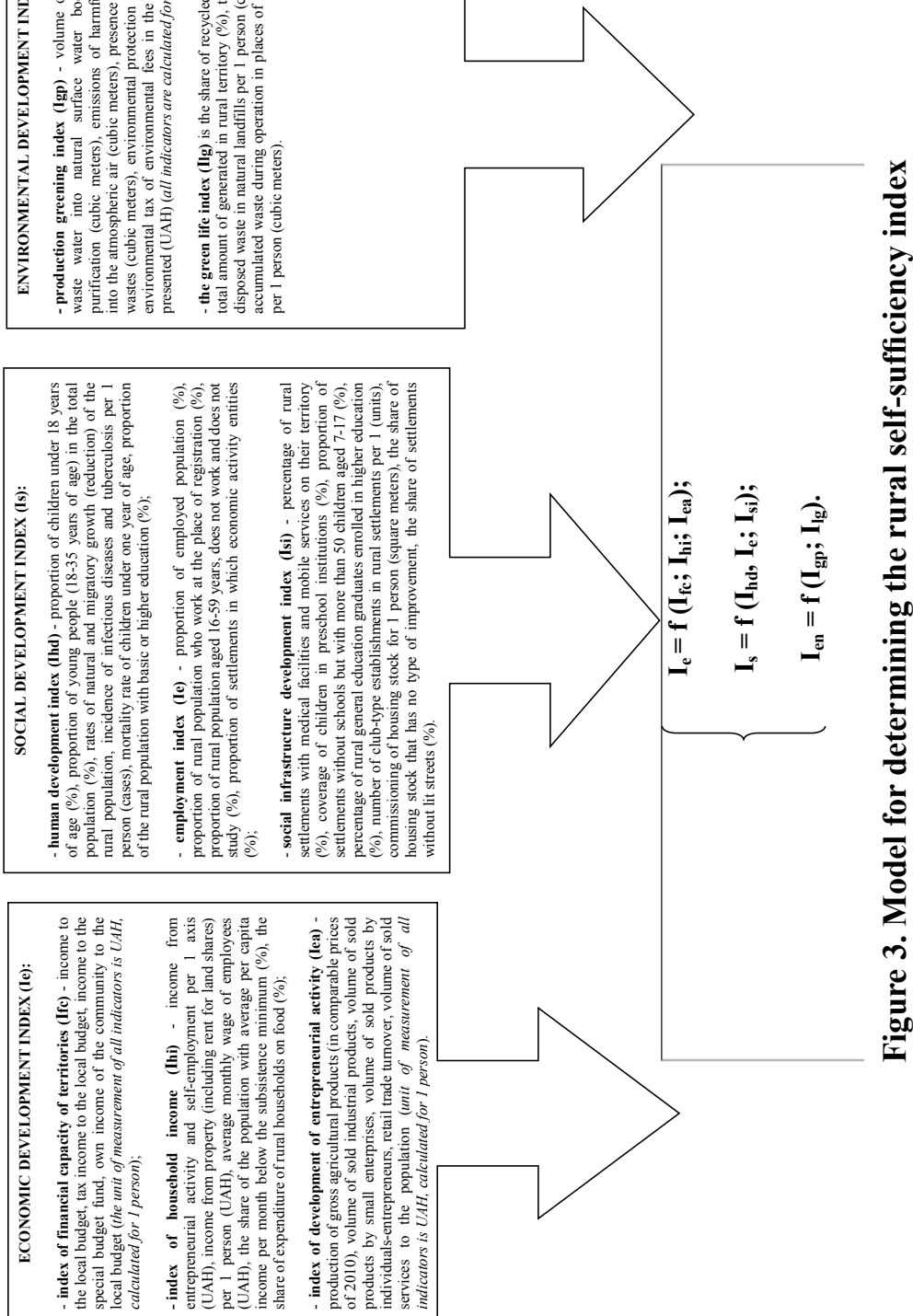
On the basis of official statistics, using the Excel computer program for automatic processing of data, the index of self-sufficiency of rural areas of Ukraine is calculated, testifying to the use of the potential of their sustainable development by only one third (table 1).

Table 1

\section{Results of calculation of self-sufficiency index of rural areas of Ukraine}

\begin{tabular}{|c|c|c|c|c|}
\hline Purpose & Index value & $\begin{array}{c}\text { Sustainable } \\
\text { development objective }\end{array}$ & Index value & $\begin{array}{l}\text { Value of the } \\
\text { index of self- } \\
\text { sufficiency }\end{array}$ \\
\hline $\begin{array}{l}\text { Building } \\
\text { the financial } \\
\text { capacity } \\
\text { of rural } \\
\text { communities }\end{array}$ & 0,49497 & $\begin{array}{l}\text { Rural economic } \\
\text { development }\end{array}$ & 0,43662 & \\
\hline $\begin{array}{l}\text { Raising rural } \\
\text { household } \\
\text { incomes }\end{array}$ & 0,32351 & $\begin{array}{l}\text { Rural economic } \\
\text { development }\end{array}$ & 0,43662 & \\
\hline $\begin{array}{c}\text { Increasing } \\
\text { income of } \\
\text { business } \\
\text { entities }\end{array}$ & 0,49139 & $\begin{array}{l}\text { Rural economic } \\
\text { development }\end{array}$ & 0,43662 & \\
\hline $\begin{array}{c}\text { Human } \\
\text { development }\end{array}$ & 0,40272 & $\begin{array}{l}\text { Improving the standard } \\
\text { and quality of life of } \\
\text { rural population }\end{array}$ & 0,39641 & \\
\hline $\begin{array}{l}\text { Increasing rural } \\
\text { employment }\end{array}$ & 0,44451 & $\begin{array}{l}\text { Improving the standard } \\
\text { and quality of life of } \\
\text { rural population }\end{array}$ & 0,39641 & 0,36407 \\
\hline $\begin{array}{l}\text { Development } \\
\text { of rural social } \\
\text { infrastructure }\end{array}$ & 0,34201 & $\begin{array}{l}\text { Improving the standard } \\
\text { and quality of life of } \\
\text { rural population }\end{array}$ & 0,39641 & \\
\hline $\begin{array}{l}\text { Greening } \\
\text { production }\end{array}$ & 0,24949 & $\begin{array}{l}\text { Conservation of natural } \\
\text { resource potential rural } \\
\text { areas }\end{array}$ & 0,25917 & \\
\hline $\begin{array}{l}\text { Greening the } \\
\text { life of the } \\
\text { population }\end{array}$ & 0,26885 & $\begin{array}{l}\text { Conservation of natural } \\
\text { resource potential }\end{array}$ & & \\
\hline rural areas & 0,25917 & & & \\
\hline
\end{tabular}

Source: developed by the authors 
In the process of management of rural areas of balance between regulation and sometimes intervention, and self-organization of society is not enough only techniques determining their depressiveness, but it is important to develop an algorithm identification of those that may, after the establishment of the appropriate mechanism develop on the principles of self-sufficiency.

\section{Conclusions}

At the present stage of economic formation, a significant step has been taken in the reform of inter-budget relations, appropriate changes to the legislation have been adopted, and mechanisms for budget financing and equalization have been changed. According to the results of the study, local self-government bodies are interested in increasing revenues to local budgets and are ready to take measures to find reserves of their filling and to improve the efficiency of administration of taxes and fees.

In addition, today local self-government is gradually moving away from the inherent consumer position. The expectations of grants are now replaced by active actions in the establishment of an effective management apparatus, directing funds to the development of communities that analyze the expenditure of budgetary funds and prevent cases of inefficient, inappropriate use of them.

In turn, the rural self-sufficiency index proposed by us can become an important tool for making management decisions by state authorities and local self-government bodies, predicting the results of their implementation and corresponding control, will contribute not only to ensuring the life of territorial communities, but also to the formation of self-sufficiency by them.

\section{References:}

1. Antonov V. V., Zaytseva L. M. Methods of complex assessment of social and economic development of the region and its administrative-territorial units (on the example of Dnepropetrovsk region). 2004. 36 p.

2. Butko M. P. Regional features of economic transformations in the transition economy. K., 2005. 476 p.

3. Varnalia Z. S. State Regional Policy of Ukraine: Features and Strategic Priorities: Monograph. K., 2007. 768 p.

4. Wozniak G. Peculiarities of inter-budget relations in the context of achieving financial viability of territorial communities. World of finance. State and local finances. 2017. № 2(51). P. 17-28. 
5. Gerasimchuk Z. V., Vakhovich I. M. Organizational and economic mechanism of formation and implementation of the development strategy of the region. Luck, 2002. 248 p.

6. State Treasury Service of Ukraine. Performance reporting. URL: http://www.treasury.gov.ua/main/uk/doccatalog/list?currDir=146477

7. State target program of Ukrainian village development for the period up to 2015: approved by Resolution CCU № 1158 of September 19, 2007. URL: http://www.minagro.kiev.ua/page/?5082

8. Decentralization of local budgets to 159 integrated territorial communities. URL: http://www.minregion.gov.ua/wp-content/uploads/2017/04/De-centr_297x210_ April-2017.pdf

9. Zhuvagina I. O., Filipishina L. N. Analysis of implementation of budgetary decentralization in the context of social and economic development of the country. Young scientist. 2017. № 4.4 (44.4). P. 35-39.

10. Law of Ukraine «On Stimulation of Development of Regions» № 2850-IV of September 8, 2005. URL: http://zakon.rada.gov.ua/cgi-bin/laws/main.cgi?nreg $=2850$

11. Zinchuk T. A. Theoretical approaches to the formation of indicators of rural economy development. Transformation of agriculture and the countryside: an anniversary collection of scientific articles. L., 2010. 416 p. P. 329-338.

12. Kazyuk Y. Strengthening the financial viability of communities: own resources and state financial support for local and regional development. URL: https://www.oecd.org/regional/regional-policy/Financial-Capacity-ofCommunities-UKR.pdf

13. Lyashenko I. M. Economic and mathematical methods and models of sustainable development. K., 1999. 236 p.

14. Morosyuk N. V., Tereshchenko V. K., Tkachuk V.A. Methodology of formation of the system of assessment of the level of development of rural areas. Agroworld. 2010. № 8. P. 2-5.

15. Morosyuk N. V. Organizational and economic foundations of sustainable development of rural areas: monograph. Nezhin: Publisher of BO Lysenko N.N., 2014. $304 \mathrm{p}$.

16. Malev A. N., Danishin B. N. Sustainable development of the region: strategic directions and mechanisms. K., 2002. 128 p.

17. Petkova L. A. Economic growth in Ukraine: regional dimension. Cherkasy: CHGTU, 2004. $272 \mathrm{p}$.

18. Cabinet of Ministers Decision № 288 of 2 April, 2009 on monitoring the socioeconomic development of small cities and towns. URL: http://zakon2.rada.gov.ua/laws/ show/288-2009

19. On Amendments to the Budget Code of Ukraine and Some Legislative Acts of Ukraine on Tax Reform: Law of Ukraine of 28 December, 2014. URL: http://zakon2.rada.gov.ua/laws/show/914-19

20. On Amendments to the Tax Code of Ukraine and Some Legislative Acts of Ukraine on Tax Reform: Law of Ukraine of December 28, 2014. URL: http: // zakon.rada.gov.ua/go/71-19 
21. Civograkov A. V. Indicators of sustainable development of the local community (How to assess the results of the local agenda-21). Minsk: Propylei, 2008. 92 p.

22. Sokolov N. A. Forecasting of social and economic development indicators of the region. S., $2005.79 \mathrm{p}$.

23. Kolova A. N., Kovalchuk A. V. Theoretical foundations of financial decentralization in conditions of public administration reform. URL: http://visnyk.academy.gov.ua/pages/dop/62/files/03055491-6112-48aa-87dcdbcaeba697f5.pdf.

24. Financial decentralization in Ukraine. First stage of success. URL: http://old.decentralization.gov.ua/pics/attachments/Buklet_finansova_decenrt_ (21.03.17).pdf

25. Focus on Sustainable Development. Nordic Key Indicators (2006). Nordic Council of Ministers. Copenhagen. $18 \mathrm{p}$.

26. Local Agenda 21 (2004). Methodological Manual Based on Experiences from Slovakia. Edited by Peter Mederly. Bratislava. 73 p.

27. Our Community Our Future: A Gide to Local Agenda 21 (1999). Canberra, 188 p.

28. Sustainable Development in Germany. Indicator Report (2007) Federal Statistical Office of Germany. Wiesbade. 59 p.

29. Sustainable Development Indicators for Sweden - a first set (2001). Statistics Sweden. Swedish Environmental Protection Agency. 52 p. 